\title{
The Rhetorical Culture of the House of Commons after 1918
}

\author{
RICHARD TOYE \\ University of Exeter
}

\begin{abstract}
The article analyses the rhetorical culture of the House of Commons in the era following the extension of the franchise in 1918, a period in which parliament saw a major influx of new Labour MPs, and also the entry for the first time of small number of women. The article discusses not only the norms and expectations surrounding parliamentary speech but also the ways in which some speaking styles and techniques became controversial. In particular, the Labour Party was accused by its opponents of practising 'rowdyism'. This allegation was part of a wider effort to undermine the party's constitutional credentials and to present it as unfit to govern. Thus, arguments about styles of arguing went the heart of broader debates over political legitimacy. To a considerable degree, Labour MPs were co-opted over time into existing codes of behaviour. But although Conservative efforts to associate their own oratorical style with political virtue did have some success, partisan factors alone are not sufficient to explain the shifts in rhetorical culture, which changed, in part, for reasons external to the institution itself. As power moved from the legislature to the executive, and as politics became increasingly professionalized, the speaking culture of the House of Commons was affected by a longstanding evolution from a discursive to a programmatic view of statecraft. Styles and techniques of parliamentary argument were thus influenced both by the changing nature of the state and by the shifting bargain between voters and the political classes in the era of universal suffrage.
\end{abstract}

\section{I} $\mathrm{n}$ the literature on inter-war British political history, the House of Commons is both everywhere and nowhere. Everywhere, because so many famous episodes occurred within the Commons: Lloyd George tapping his forehead to hint that Lord Northcliffe was insane; Baldwin urging conciliation of the unions with the prayer 'Give peace in our time, O Lord'; Churchill being howled down during the Abdication crisis; the rapturous response to Chamberlain when he announced he was to visit Hitler at Munich, averting war; and so forth. Nowhere, because although no account of the period would be complete without

I would like to thank Laura Beers, David Thackeray, two anonymous referees, and the attendees at a lecture and several seminars in the UK and Japan, for their comments on earlier versions of this article. Any errors that remain are my own responsibility. I would also like to thank John Whitley and the Whitley family for granting me access to the papers of J. H. Whitley in advance of their deposit at the University of Huddersfield. 
reference to such occasions (and to multitudes of lesser known ones), the Commons itself is usually treated simply as the venue for political activity, not as something that needs to be analysed in its own right as an institution that shaped the events that took place within it. It is, in other words, generally taken for granted, or to put it another way, hidden in plain view.

Perhaps this is because there is much, in terms of the parliamentary ceremony and procedure of the period, which was already long established and still seems familiar today; whereas, for example, the conduct of elections has changed much more dramatically and thus seems more obviously in need of examination and explanation. ${ }^{1}$ Yet we cannot assume that a similarity of outward forms implies continuity of social and political meanings. Moreover, the failure to interrogate the significance that the Commons held for contemporaries at the dawn of the age of universal suffrage has resulted in a widespread failure to investigate the central role that it still played in national political life. Analysis of the rhetorical culture of the Commons during this crucial period - that is to say, how norms and expectations surrounding parliamentary speech shaped the messages that were delivered - allows us to understand how the institution was understood not only by MPs themselves but by the wider political class. Although there were only minor procedural reforms during the period, political understandings of the interwar Commons were contentious. Debates about what kinds of behaviours were appropriate within it were often cast in terms of appeals to supposedly unchanging traditions, yet these were often the mask for highly partisan interventions intended to undermine political opponents' claims to be suitable to govern. Parties and individuals were attacked not only for what they said but for how they said it. Within parliament as much as without, arguments about styles of arguing went to the heart of broader debates over political legitimacy. Of course, at a time of economic crisis, important changes in the class structure of society, and conflicting currents of religiosity and secularism, practically all institutions were the subject of greater or lesser degrees of questioning; nor had parliament escaped such questioning in the decades before 1918. But although the significance of inter-war disputes about parliamentary conduct should not be overstated, they can be seen as an important and neglected component of broader controversies about 'constitutionalism' and the forms of political behaviour that attended it. To put it another way, controversies over parliamentary style were indicative of more general disputes over the culture and ideology of British politics in this period.

1 Jon Lawrence, Electing Our Masters: The Hustings in British Politics from Hogarth to Blair (Oxford, 2009). See also Kit Good, "Quit ye like men”: platform manliness and electioneering, 1895-1939', in Matthew McCormack (ed.), Public Men: Masculinity Politics in Modern Britain (Basingstoke, 2007), pp. 143-64. 
These arguments took place at a time when the role of the Commons, in relation to the state as a whole, was undoubtedly shifting. Keith Middlemas has argued that 'Long before 1945, Parliament had ceased to be the supreme governing body ... parties and Parliament subordinated themselves to the administrative and managerial powers of the state apparatus. ${ }^{2}$ But what did this apparent decline (which was also alleged by some contemporaries but disputed by others) mean in terms of what MPs actually did, and to what extent was it driven by endogenous rather than exogenous factors? The history of the Commons at this time has been presented largely as one of a regrettable failure to modernize procedures deriving from 'its incredible and seemingly innate conservatism' in such matters. ${ }^{3}$ By contrast, the role of the Commons as a site for and an object of public discussion has not been much considered, even though - as in the earlier period - it remained central to much contemporary political reporting. Brian Harrison pointed out twenty-five years ago that parliamentary speech is 'an aspect of politics surprisingly neglected by historians'. ${ }^{4}$ Since then, Christopher Reid has provided a valuable study that deals with the latter part of the eighteenth century, and Joseph Meisel has made an important contribution to the study of Commons oratory in the Gladstonian era. ${ }^{5}$ We also know a fair amount about the role of parliament and its members in general, and about some particular subsets of MPs (notably women); and also something about parliamentary humour. ${ }^{6}$ However, important gaps in our knowledge remain.

Meanwhile, scholars of modern Britain have examined political language in a multitude of useful ways. However, it is only quite recently that a small body of them have begun to conceive their technique

\footnotetext{
${ }^{2}$ Keith Middlemas, Politics in Industrial Society: The Experience of the British System since 1911 (London, 1979), p. 22.

${ }^{3}$ S. A. Walkland (ed.), The House of Commons in the Twentieth Century (Oxford, 1979), p. 2; Philip Norton, 'Winning the war but losing the peace: the British House of Commons during the Second World War', Journal of Legislative Studies, 4 (1998), pp. 33-51.

${ }^{4}$ Brian Harrison, 'Women in a men's house: the women MPs, 1919-1945', Historical Journal, 29 (1986), pp. 623-54, at p. 629.

5 Christopher Reid, Imprison'd Wranglers: The Rhetorical Culture of the House of Commons 1760-1800 (Oxford, 2012); Joseph S. Meisel, Public Speech and the Culture of Public Life in the Age of Gladstone (New York, 2001), ch. 2. An indication of the growing interest in the issue with respect to the later period is the publication of Philip Norton (ed.), Eminent Parliamentarians: The Speaker's Lectures (London, 2012), which contains helpful insights on the parliamentary contributions of key figures such as Lloyd George.

${ }^{6}$ Michael Rush, The Role of the Member of Parliament since 1868: From Gentlemen to Players (Oxford, 2001); Stuart Ball, 'Parliament and politics in Britain, 1900-1951', Parliamentary History, 10 (2008), pp. 243-76; Paul Seaward and Paul Silk, 'The House of Commons', in Vernon Bogdanor (ed.), The British Constitution in the Twentieth Century (Oxford, 2003), pp. 139-88; Patrick Dunleavy and G. W. Jones with Jane Burnham, Robert Elgie and Peter Fysh, 'Leaders, politics and institutional change', in R. A. W. Rhodes and Patrick Dunleavy (eds), Prime Minister, Cabinet and Core Executive (Basingstoke, 1995), pp. 275-97; Harrison, 'Women in a men's house; Alvin Jackson, ' "Tame Tory hacks?": the Unionist MPs at Westminster', Historical Journal, 54 (2011), pp. 453-75; P. J. Waller, 'Laughter in the House: a late nineteenth and early twentieth century parliamentary survey', Twentieth Century British History, 5 (1994), pp. 4-37.
} 
explicitly as rhetorical analysis, and much of the focus is on extraparliamentary speech. ${ }^{7}$ In the existing literature, rhetoric is often treated as something which is purely the product of the individual orator's skill (or lack of it). Examining rhetorical culture allows us to see more clearly that it is in fact a social phenomenon, in which audience expectations play a crucial part. In the case of the Commons, these expectations were conditioned by a set of rules and conventions (the latter established by tradition rather than by written authority) which themselves were often moot and were capable of flexible interpretation depending on circumstance. ${ }^{8}$ These rules were very important, but we know from the very different ways in which the 'Westminster model' has played out in parliaments from Australia to the Caribbean that rules alone do not determine rhetorical culture. ${ }^{9}$

Sandra Harris has considered the modern House of Commons as a 'community of practice', in which newcomers adopt the socio-cultural habits of the institution (including its rhetorical norms) through 'situated learning' - a concept certainly familiar to readers of political memoirs that compare joining the Commons to joining a new club or school. ${ }^{10}$ This article will use the idea as a framing device in order to explore the inter-war period, with particular reference to the impact of a large body of newcomers with distinct class characteristics, i.e. the 1920s influx of Labour MPs, as well as a small number of women. The specific features of this era lead to broader questions about parliament and parliamentary discourse, which in turn shed light on the rhetoricalpolitical culture of Britain more generally.

It will be argued here that the changing composition of the Commons did not simply involve the adjustment of newcomers to a static rhetorical culture; the culture itself changed, not least because rhetorical

\footnotetext{
7 Max Atkinson, Our Masters' Voices: The Language and Body Language of Politics (London, 1984); H. C. G. Matthew, 'Rhetoric and politics in Britain, 1860-1950', in P. J. Waller (ed.), Politics and Social Change in Modern Britain (Brighton, 1987), pp. 34-58; Philip Williamson, Stanley Baldwin: Conservative Leadership and National Values (Cambridge, 1999); Jonathan Charteris-Black, Politicians and Rhetoric: The Persuasive Power of Metaphor (Basingstoke, 2005); Frank Myers, 'Harold Macmillan's "winds of change" speech: a case study in the rhetoric of policy change', Rhetoric and Public Affairs, 3 (2000), pp. 555-75; Alan Finlayson and James Martin, " "It ain't what you say ...": British political studies and the analysis of speech and rhetoric', British Politics, 3 (2008), pp. 445-64; Lawrence, Electing Our Masters; Ben Jackson, 'The rhetoric of redistribution', in John Callaghan, Nina Fishman, Ben Jackson and Martin McIvor (eds), In Search of Social Democracy: Responses to Crisis and Modernisation (Manchester, 2009), pp. 23351; Richard Toye, 'The rhetorical premiership: a new perspective on prime ministerial power since 1945', Parliamentary History, 30 (2011), pp. 175-92. By contrast, the literature on modern American political rhetoric is enormously more extensive. A key text is Jeffrey Tulis, The Rhetorical Presidency (Princeton, NJ, 1987).

8 Note on 'Peers' title to Right Honourable', c.Dec. 1927, Parliamentary Archives, London, HC $50 / 2 / 4$.

9 Matthew Engel, 'Up a gum tree', FT Magazine, 26 Nov. 2010; Matthew Louis Bishop, 'Slaying the "Westmonster" in the Caribbean? Constitutional reform in St. Vincent and the Grenadines', British Journal of Politics and International Relations, 13 (2011), pp. 420-37.

${ }_{10}$ Sandra Harris, 'Being politically impolite: extending politeness theory to adversarial political discourse', Discourse \& Society, 12 (2001), pp. 451-72, at p. 453.
} 
practice, although subject to formal rules, was controversial because of its links to other values, which were also often articulated by people who were not themselves MPs. Hence the importance of considering debates about parliamentary practice that took place outside parliament as well as within it. Parliamentary reporting (with its veiled assumptions about correct behaviour) and partisan commentary may not only have influenced outside perceptions of rhetoric but may itself have influenced MPs' speech-making practices. MPs were performers who read their own notices and, it seems certain, adjusted their techniques accordingly. Descriptions of Commons proceedings (which were rarely if ever neutral) and arguments about them thus affected the conduct of argument within the Commons itself. This was not of course a new phenomenon, but the way in which it operated was affected by the changing media culture of the time, which put an increasing emphasis on 'celebrity' ${ }^{11}$ It is impossible, then, to consider the Commons exclusively 'in its own terms' without discussion of the broader political culture of which it was a part. Equally, the high politics of 'parliamentary manoeuvre' can only be fully grasped in the light of the rhetorical culture that surrounded it. ${ }^{12}$ Indeed, parliamentary manoeuvre in the literal sense as opposed to generalized political manoeuvres carried out by people who happened to be Members of Parliament - was itself a dying art. As power shifted to the executive, the kind of grand play carried out by Disraeli on the floor of the House of Commons in 1867 without reference to the cabinet was no longer a possibility. ${ }^{13}$ Thus the rhetorical culture of the House of Commons was affected not only by the 'impact of Labour' but by changes in the nature of the state.

Jon Lawrence's persuasive account of 'the transformation of British public politics' after the First World War suggests that politicians became increasingly keen to distance themselves from the rowdy and disruptive behaviour that had become a well-established part of electoral ritual. ${ }^{14}$ How did parliament fit in to this picture, and what part did Commons rhetoric play in what Alan Finlayson and James Martin have labelled the 'symbolic ritual dimension of politics'?! (It is appropriate to focus specifically on the Commons, as it was now firmly established as the dominant chamber.) Disruption, it must be strongly emphasized, was not new; nor were the arguments that surrounded it, although their form changed. One past disruptive influence, the Irish

${ }^{11}$ Laura Beers, 'A Model MP? Ellen Wilkinson, gender, politics and celebrity culture in interwar Britain', Cultural and Social History, 10 (2013), pp. 231-50.

${ }_{12}$ Maurice Cowling, The Impact of Labour 1920-1924: The Beginnings of Modern British Politics (Cambridge, 1971); idem, The Impact of Hitler: British Politics and British Policy 1933-1940 (Cambridge, 1975).

13 Idem, 1867: Disraeli, Gladstone and Revolution: The Passing of the Second Reform Bill (Cambridge, 1967), pp. 267-86.

14 Jon Lawrence, 'The transformation of British public politics after the First World War', Past \& Present, 190 (2006), pp. 185-216.

15 Finlayson and Martin, “It ain't what you say ...", p. 448. 
Parliamentary Party, was defunct after the war; and the new Sinn Féin MPs refused to take their seats. In spite of some interest in the idea amongst a minority of left-wingers, the Labour Party never did imitate the Parnellite efforts to obstruct all government business. ${ }^{16}$ It was, however, more interested in parliamentary and constitutional reform than is generally thought. ${ }^{17}$ Moreover, the extensions of the franchise in 1918 and 1928 - accompanied by the election of the first women MPs and a new influx of Labour members - were developments potentially threatening to the self-appointed guardians of parliamentary tradition. In practice, the women were too few in number to make a radical difference to the Palace of Westminster's atmosphere; the surge in working-class representation was a source of much greater anxiety and controversy. Class was in many respects fundamental to the way MPs presented themselves, as seen in issues of dress, accent and demeanour, and the Commons was at times a cockpit of class tension (if not class warfare). ${ }^{18}$ The politics of clothing and gesture, the competition for dominance of physical space within the chamber, and the construction of 'image events' for wider public consumption, were all aspects of the evolving rhetorical culture of the Commons. ${ }^{19}$ Moreover, broad societal concerns, such as some Labour MPs' desire to present themselves as champions of the poor and unemployed, were reflected in rhetorical practices, such as symbolic disruption tactics, which were in turn deplored by Liberals and Conservatives.

At the same time, the main parties hotly contested each other's commitment to parliament - and to the constitution more generally - frequently alleging extremist or dictatorial tendencies in their opponents. (At the same time, as is often rightly observed, Stanley Baldwin in particular made efforts to suggest that Labour would be properly integrated into the constitution as a responsible party of government, although he sometimes suggested the opposite too.) Such fears - or alleged fears - were of course often articulated for tactical reasons. But there was also a genuine element to them, and they were exacerbated both by the continuation of the governmental methods of the wartime state, which had seen the growth of an apparently unaccountable bureaucracy and the co-option of unelected businessmen to positions of power, and by the rise of militant mass trades unionism. For example,

16 David Howell, MacDonald's Party: Labour Identities and Crisis, 1922-1931 (Oxford, 2002), pp. $29,35$.

${ }_{17}$ For a compelling exposition of this viewpoint, see Miles Taylor, 'Labour and the constitution', in Duncan Tanner, Pat Thane and Nick Tiratsoo (eds), Labour's First Century (Cambridge, 2000), pp. $151-80$.

${ }_{18}$ For such questions beyond the Commons, see Nicholas Owen, 'MacDonald's parties: the Labour Party and the "aristocratic embrace", 1922-31', Twentieth Century British History, 18 (2007), pp. 1-53.

${ }_{19}$ Michael J. Braddick, 'Introduction: the politics of gesture', Past \& Present, suppl. 4 (2009), pp. 9-35; Davi Johnson, 'Martin Luther King Jr.'s 1963 Birmingham campaign as image event', Rhetoric \& Public Affairs, 10 (2007), pp. 1-25. 
during the Lloyd George coalition, the independent (Asquithian) Liberals claimed that they were the only party that actually believed in parliamentary methods. Whereas the coalition leaders treated the Commons 'with open contempt, preferring to act through irresponsible committees, controllers, and placemen', the commitment of a section of the Labour Party to 'direct action' implicated all its members in an idea that threatened 'democratic collapse'. ${ }^{20}$ Conservatives and Lloyd George Liberals made similar attacks on Labour over 'direct action', accusing the party of sidelining parliament in favour of union activity. ${ }^{21}$ Labour attacked Liberal opportunism and Tory cynicism, presenting itself by contrast as the defender of political honesty and 'proper Parliamentary action'. ${ }^{22}$ In an era notable for 'the failure of political extremism' and the survival of parliamentary government, it is striking how contentious parliament itself actually was. ${ }^{23}$

The resolution of the paradox lies in the fact that most political actors, in denying the parliamentary credentials of others, were not rejecting parliament themselves but rather laying claim to it. Labour's 'parliamentarism' may not have been as slavish as has been alleged by Ralph Miliband and other Marxist critics, but even proponents of 'direct action' tended to see it as a complement to parliamentary methods rather than as an alternative to them. ${ }^{24}$ Laying claim to parliament meant more than arguing for a programme and putting up candidates for election - it meant demonstrating 'fitness to govern', through proper deportment as much as suitable policies. (Labour was considered vulnerable on this score, and was famously charged by Churchill with being 'unfit to govern'. $)^{25}$ Behaviour within the Commons provided a test of this, and challenging the behaviour of opponents was a way of casting doubt on their overall legitimacy. This is not to say, however, that the norms were agreed or that the only way to win advantage was through replication of existing codes. Conduct that Conservatives and Liberals presented as disruptive and inappropriate could be claimed by Labour as a sign of 'virile vigour'. ${ }^{26}$ Whereas Labour's enemies claimed that its actions in the Commons were 'disgraceful', it supporters could argue that 'the Labour Party has been to the forefront in debate and has argued with a force and knowledge which has given a

20 'How to get real progress', in Liberal Publication Department, Pamphlets and Leaflets for 1919 (London, 1920).

${ }^{21}$ See, for example, ' "Labour” MPs' new leader', The Popular View, Dec. 1922, and 'The failure of the opposition', Lloyd George Liberal Magazine, Aug. 1921.

22 'Labour leader's vision', The Times, 3 Dec. 1923.

${ }^{23}$ Andrew Thorpe (ed.), The Failure of Political Extremism in Inter-War Britain (Exeter, 1989).

${ }^{24}$ Ralph Miliband, Parliamentary Socialism: A Study in the Politics of Labour, 2nd edn (London, 1972); Richard Toye, "Perfectly parliamentary"? The Labour Party and the House of Commons in the interwar years', Twentieth Century British History, 25 (2014), pp. 1-29.

25 'Mr. Churchill on Russia', The Times, 16 Feb. 1920.

26 J. Ramsay MacDonald, 'The party in parliament', Socialist Review, Jan. 1923. 
new vitality to Parliament. ${ }^{27}$ Before exploring the significance of such claims, it will be convenient to begin with a description of the factors that governed the rhetorical atmosphere of the Commons, and the relationships between these and contemporary assumptions about the 'proper' technique of Commons speech.

The Commons of 1918 was already much changed from that of the mid-Victorian period, largely because of the disruptive tactics of the Irish Parliamentary Party, especially in the 1880s, which had forced major procedural innovations in order to expedite the business of the House. Ireland was also at the root of much of the disruption that took place during the Edwardian period of Liberal government, now generated by Unionists opposed to Home Rule. In addition, the presence from 1906 of a substantial number of Labour MPs (thirty were elected that year and their numbers increased in 1910) marked a significant change in atmosphere. Controversy surrounding the procedure and purposes of parliament, then, was already a fact of political life.

Nevertheless, there were some unchanging elements. Speech within the Commons was governed first and foremost by the physical arrangements of the Chamber, as established by the rebuilding of the Houses of Parliament after the great fire of 1834. Rows of opposing benches, separated by a gangway, but without enough space to seat all members at once, enforced an atmosphere that was both adversarial and intimate. Speaking from the backbenches, with no despatch box to lean on, could be alarming, as Harold Macmillan recalled to his biographer: 'when you stand up to speak, the bench in front of you seems to catch you just below the knee and gives you the impression that you are about to fall headlong over' ${ }^{28}$ The rhetorical technique that these arrangements tended to enforce was widely considered to be very different from that required for platform speaking. More than that, the link between physical space and technique was often held to result in a particular form of political and rhetorical virtue. This view was expressed eloquently by Churchill, who wrote of how the small chamber produced

a conversational style of speaking, which has long been held to be the model of English Parliamentary life. How much better this is than foreign assemblies, where they all sit in a semi-circle, and everyone has a place, or even a desk, which he can bang when he is displeased, and where every speaker goes up to harangue an audience scattered through a large arena.

\footnotetext{
27 'Notes of the month', Lloyd George Liberal Magazine, May 1923; 'Vote for [Henry H.] Slesser' (Labour Party leaflet for the Leeds Central by-election of 26 July 1923), Conservative Party Archive, PUB 229/1/, Bodleian Library, Oxford.

28 Alistair Horne, Macmillan, 1894-1956 (London, 1988), p. 75.
} 
The essential of keen debate is the sense of a crowd, clustering together, craning forward, gathering round the speaker, with the cheers flung back from side to side. ${ }^{29}$

The 'conversational style' identified by Churchill was certainly now in vogue, but his claim that it was a long-established model was only partially convincing. It is true that, as R. G. Thorne observes, Robert Peel 'made a conscious effort to cultivate plain and unadorned statement, an augury of future form'. ${ }^{30}$ But Gladstone's remarkable Commons speeches, with their 'involved phrases and parentheses', were scarcely conversational, and by the inter-war years might no longer have found favour. ${ }^{31}$ It has been suggested, in fact, that Churchill's own orotund style represented a hangover from the nineteenth century, and that he was out of touch with the plainer modern technique. ${ }^{32}$ Obliged to make multiple off-the-cuff speeches during his 1930s India campaign, he was a late (and as it turned out temporary) convert to a different method. He wrote to his wife that the correct technique consists 'in my (mature) judgement of selecting three or four absolutely sound arguments and putting these in the most conversational manner possible. There is apparently nothing in the literary effect I have sought for forty years! ${ }^{33}$ It does appear that conversationalism was becoming hegemonic (although it was not unchallenged). As one Tory commentator remarked in 1924, "modern Parliamentary debate has become conversational rather than oratorical or even eloquent.' Moreover: 'as a rule the House neither expects nor receives anything which would seem inappropriate at a Town Council meeting or a gathering of company shareholders, and, to the scandal of the older Parliamentary hands, new members address the House for the first time with coolness and assurance; they speak with fatal fluency. ${ }^{34}$ Many Labour MPs, including Ramsay MacDonald, had gained experience in mock-Westminster 'local parliaments', local councils, trade unions and other rule-bound organizations and thus had a grounding in parliamentary ritual and rhetorical technique. ${ }^{35}$ Conservative and Liberal MPs were likely to have got their own training in university debating societies, as indeed were the significant number of middle-class

${ }^{29}$ Winston Churchill, 'Memories of parliament as a novitiate member', News of the World, 18 Dec. 1938, in Michael Wolff (ed.), The Collected Essays of Sir Winston Churchill, II (London, 1976), pp. 415-21, at p. 415. Churchill echoed these arguments closely in his speech advocating rebuilding the chamber on the existing model after it was bombed during the Second World War: Parliamentary Debates, House of Commons, 5th ser., vol. 393, 28 Oct. 1943, cols 403-9.

30 R. G. Thorne, The House of Commons 1790-1820, I: Introductory Survey (London, 1986), p. 344 .

${ }_{31}$ H. Snell, Daily Life in Parliament (London, 1930), p. 46.

32 Robert Rhodes James, Churchill: A Study in Failure 1900-1939 (London, 1970), p. 28; David Cannadine, In Churchill's Shadow: Confronting the Past in Modern Britain (London, 2002), pp. $97-8$.

${ }_{33}$ Winston Churchill to Clementine Churchill, 13 April 1935, in Speaking for Themselves: The Personal Letters of Winston and Clementine Churchill, ed. Mary Soames (London, 1998), p. 399.

${ }^{34}$ Robert S. Angus, 'Oratory in the House', The Man in the Street, Sept. 1924.

35 Ross McKibbin, The Ideologies of Class: Social Relations in Britain (Oxford, 1991), pp. 22-3. 
ex-Liberals on the Labour benches. It is worth noting that although the new influx of Labour MPs increased the working-class element in the Commons, the percentage of Labour MPs from working backgrounds declined, as the party gained middle-class recruits. ${ }^{36}$

Non-conversational forms of speech could still be successful. The Labour MP E. Rosslyn Mitchell observed to the Conservative Duff Cooper of the latter's maiden speech: 'I was told that the House listened only to the peculiar and irritating style, known as the House of Commons manner, which is made up of hesitation, eh-ahing and a crowd of clichés of the "venture to suggest", "make bold to say" sort. Now you have proved what I was told is untrue. ${ }^{37}$ However, forcefulness - or a certain variety of it - could come in for criticism. A regular Conservative charge against Labour was that the party had showed disrespect for parliament by importing methods of the platform. A typical cartoon in a Tory publication showed 'Sam Slogger' and 'Bull Bellows' as figures likely to secure adoption as socialist candidates, because of their capacity for parliamentary rowdyism. ${ }^{38}$ Another Conservative magazine commented sarcastically in 1924 that 'The possession of a strong voice is a great asset in this Parliament, where a member often has to contend against the leather-lunged interruptions of socialists who have had a stiff street corner training. ${ }^{39}$ Moderate Labour leaders themselves applied this critique to their more radical followers, Ramsay MacDonald expressing irritation with left-wingers who 'do no work but much talking \& wish to turn the floor of [the] House into a sort of national street corner soap box'. ${ }^{40}$ There was also a generational issue here; some veterans of the pre-war PLP, such as MacDonald, were wont to look down on the newcomers' indiscretions, whereas others took a more positive view of their tutelary role.

Yet it should be noted that elements of a platform manner were potentially compatible with successful Commons speaking. In his time, Lloyd George had been attacked for bringing 'Limehouse' methods into the chamber, but - like the populist Lord Randolph Churchill before him - he was undoubtedly a skilled parliamentarian. ${ }^{41}$ Claims that platform methods did not work in the Commons were not, in fact, objective statements about the demands that the building or the atmosphere imposed, but rather a way of linking one's opponents' supposed lack of

\footnotetext{
36 Rush, The Role of the Member of Parliament.

37 E. Rosslyn Mitchell to Duff Cooper, 15 Dec. 1924, quoted in Duff Cooper, Old Men Forget (London, 1954), p. 140.

38 The Popular View, May 1923. It is not clear how wide the circulation of this and similar publications was. Their true significance - and this also goes for Labour and Liberal publications - probably lay in their provision of arguments and information that could be used by party activists, candidates and MPs. In other words, they helped set the agenda.

39 'Personalities', The Man in the Street, Aug. 1924.

40 MacDonald diary, 3 Dec. 1924, PRO 30/69/1753, The National Archives, Kew, London [hereafter TNA]. Anyone wishing to quote these diaries is obliged to explain that MacDonald meant them simply 'as notes to guide and revive memory' and did not intend them to be published.

41 Waller, 'Laughter in the House', pp. 36-7.
} 
decorum to their alleged lack of understanding of (or even contempt for) parliamentary traditions. This is not to say that the physical arrangements did not enforce real constraints, only to point out that these arrangements were also discussed in ideologically charged terms, which demeaned 'foreign assemblies' and attempted to impose rhetorical conformity on potentially threatening newcomers. As will be seen below, the techniques that were said to be demanded by the building were linked to wider cultural (and class) values concerning deportment and emotional self-restraint.

Rhetorical culture was affected not only by the layout of the chamber but by the rules of procedure. These derived in part from formal published standing orders, partly from Erskine May's Parliamentary Practice (an authority, not a rule-book, first published in 1844 and regularly revised) and partly from the case-law of accumulated rulings of successive Speakers. ${ }^{42}$ (However, no Speaker could bind his successors. ${ }^{43}$ The rules were very complex and were probably understood in their entirety by very few MPs. This contributed to the sensation - probably most frequent amongst privately educated members - that arriving at the Commons for the first time was like arriving at a new school, with the Speaker as headmaster. ${ }^{44}$ MPs learnt through observation, by instruction by established members, and by being corrected in their mistakes. ${ }^{45}$ As the parliamentary sketch-writer Alexander Mackintosh observed, neophytes came up against many 'Don'ts': 'Don't step between the member who is speaking and the Chair. Don't read or display a newspaper. Don't mention any member by name. Don't refer specifically to speeches or proceedings in the House of Lords. . . Cries of "Order" arrest the offender. ${ }^{46}$ Such were the methods of parliament's 'community of practice'.

These collective efforts to regulate rhetorical micro-behaviours sometimes encountered resistance from left-wingers at the outset of their Commons careers. During his maiden speech on the topic of unemployment, the fiery radical James Maxton inadvertently referred to another MP by name and was called to order. He corrected himself, before

${ }^{42}$ Harold Macmillan, Winds of Change 1914-1939 (London, 1966), p. 157.

${ }^{43}$ Lord Hemingford, Back-Bencher and Chairman: Some Parliamentary Reminiscences of Lord Hemingford, KBE, PC (London, 1946), p. 31.

${ }^{44}$ Macmillan, Winds of Change, p. 156; E. D. Morel, 'First impressions of Westminster and the party', New Leader, 1 Dec. 1922; Snell, Daily Life in Parliament, p. 4; Viscount Swinton, I Remember (London, 1949), p. 14.

${ }_{45}$ Labour MPs who had previous parliamentary experience as Liberals seem to have taken a significant role in advising their new colleagues. For the roles of Josiah Wedgwood and H. B. Lees-Smith respectively, see Ernest Thurtle, Time's Winged Chariot: Memories and Comments (London, 1945), p. 72, and Andrew Bonar Law to George V, 12 April 1923, Stanley Baldwin Papers, 60, Cambridge University Library. Bonar Law and Baldwin's letters to the king were likely drafted by secretaries or junior whips, but even with this caveat they remain valuable sources for Conservative attitudes to parliament.

46 Alexander Mackintosh, Echoes of Big Ben: A Journalist's Parliamentary Diary (1881-1940) (London, 1946), p. 94. 
adding 'but it does not matter a damn'. ${ }^{47}$ Of this episode, his colleague Thomas Johnston wrote: 'is the disorder not in the minds of the vulgar yahoos who, dull to the sorrows of the children of the poor, cried for the strict observance of a useless formula? ${ }^{48}$ Quickly enough, though, the expected habits were internalized, even by critics such as Maxton and Johnston. By the late 1920s some Conservatives were gloating that many former Labour 'scoffers' were now strong upholders of parliamentary tradition, having supposedly reached an understanding of the true significance of "the ancient forms and formulas'.

\section{II}

The expected micro-behaviours were easy enough to learn, but MPs also had to negotiate a range of informal (and sometimes flexible) rhetorical expectations. First, of course, there was the ritual of the maiden speech. This was not supposed to be controversial, and - as long as the member concerned made clear that they were speaking for the first time - it was not normal to interrupt. Whatever the quality, polite compliments would be paid by the next speaker. Some newcomers made controversial maidens because no-one had explained the rule to them. ${ }^{50}$ Others, however, deliberately broke the convention, either out of strength of feeling, or because they aspired to imitate the success of previous brilliant maidens, such as that of F. E. Smith in 1906. Such efforts might go wrong, but the breach of convention was not in fact completely unconventional. There were other informal understandings. If one was planning to attack another member, it was the done thing to notify them in advance. Parliamentary Private Secretaries (PPSs) were not supposed to speak often. ${ }^{51}$

MPs were expected to refer to previous speeches, not simply to deliver prepared orations. Accordingly, they were not supposed to read their speeches, although, according to Austen Chamberlain, they were now not infrequently to be seen doing so. ${ }^{52}$ (Bonar Law's capacity to speak entirely without notes added to his remarkable command of the House; by contrast he was not a notably effective extra-parliamentary speaker. $)^{53}$ However, the boundaries of what was in order were not always clearly defined, and could be tested. As Snell explained in his booklet Daily Life in Parliament (1930),

47 Gordon Brown, Maxton (Edinburgh, 1986), p. 125.

48 Thomas Johnston, 'The Wild Red Men', Forward, 23 Dec. 1922.

49 'Quill, MP', 'Pen pictures from parliament', Home and Politics, Nov. 1928.

50 See, for example, Leah Manning, A Life for Education: An Autobiography (London, 1970), p. 88.

51 C. R. Attlee, As it Happened (London, 1954), p. 59

52 Special Report from the Select Committee on Procedure on Public Business (London, 1931),

p. 222. This committee never issued a report but it did publish the evidence it gathered.

53 Oswald Mosley, My Life (London, 1968), p. 166. 
A member may not refer to another honourable member as an 'insolent swine,' but if he were to call him an 'arrogant porker' it might not be challenged. It is quite clearly out of order to call another member a 'liar,' but if you were to say that 'the statement of the hon. Member, when regarded from the standpoint of strict accuracy, leaves something to be desired,' the Chair would take no notice, although the meaning intended would be the same in both cases. ${ }^{54}$

Indeed, finding ways to stretch or even break the rules without being called to order was part and parcel of the parliamentary game. ${ }^{55}$

'Nothing is so important as constant attendance at the House', averred the then Liberal MP William Wedgwood Benn to his diary in $1922 .{ }^{56}$ This, however, needs to be understood in context. As a rule, and except on Fridays, the House met at 2.45 p.m. and adjourned at 11.30 p.m., although if standing orders were suspended it could sit later. (All-night sittings were a possibility but became rarer by the early 1930s. $)^{57}$ This meant that members had the morning free for other activities, and it is obviously relevant to the question of rhetorical culture that barrister MPs speaking in debate in the Commons might well have been speaking in the courts earlier the same day. (Not that legal training was a guarantee of Commons success: Patrick Hastings, Labour's first attorney-general, was a parliamentary failure. $)^{58}$ Moreover, 'attendance at the House' could mean many things besides involvement in set-piece oratory. There were the rituals of Question Time - the numbers of questions were growing - and the raising of points of order, more and more of them spurious. ${ }^{59}$ In addition, an increasing amount of legislative work was being done in committee. ${ }^{60}$ There were also party committees, notably the system of subject-based committees established after 1924 by Conservative Chief Whip B. M. Eyres-Monsell to keep the Tory rank-and-file in touch with

${ }^{54}$ Snell, Daily Life in Parliament, pp. 48-9, following Spencer Leigh Hughes, Press, Parliament and Platform (London, 1918), pp. 107, 110.

${ }_{55}$ Thurtle, Time's Winged Chariot, pp. 72-3; William Wedgwood Benn diary, 16 June 1924, Stansgate Papers ST 66, Parliamentary Archives.

${ }^{56}$ Benn diary, 16 May 1922, Stansgate Papers ST 66. See also Jack Jones, My Lively Life (London, 1928), p. 77. Benn, it should be noted, was notorious for his obstructive parliamentary tactics and, in order to carry these out, probably placed more importance than most MPs did on being present in the chamber. Note also that attendance was more important for opposition MPs than for government ones, at least if the latter had a big majority.

57 W. Ivor Jennings, Parliament (Cambridge, 1939), p. 88; Nick Smart (ed.), The Diaries and Letters of Robert Bernays, 1932-1939: An Insider's Account of the House of Commons (Lewiston, 1996), p. 11 (entry for 3 Nov. 1932).

${ }^{58}$ Frank Gray, Confessions of a Candidate (London, 1925), pp. 140-1. According to Hastings himself, 'my first experience of the House of Commons was a bitter disappointment': The Autobiography of Patrick Hastings (London, 1948), p. 229.

59 Special Report from the Select Committee on Procedure, p. 227.

${ }^{60}$ For the significance of parliamentary committees, see "They have made their mark entirely out of proportion to their numbers": women and parliamentary committees, c.1918-1945', in Julie Gottlieb and Richard Toye (eds), The Aftermath of Suffrage: What Happened after the Vote Was Won (Basingstoke, forthcoming). 
the leadership. ${ }^{61}$ There were external committees too and, for some, the responsibilities of acting as a PPS to a minister. Such activities - and what Harold Nicolson called 'constituency fuss' - tended to drag MPs away from the House and the Chamber, often against their instinct that it ought to be the central focus of their efforts. ${ }^{62}$ Their anxieties on this score perhaps reflected a somewhat unwarranted fear of missing out, rather than a true appreciation of where power actually now lay. The Chamber did not often seem like the true centre of the action to those who were actually there. 'The real work is being done in the departments', noted the Labour MP Rennie Smith after a boring day listening to speeches. 'We are like a lot of silly sheep, looking on. ${ }^{.63}$

The fact that they now spent less time in the Chamber did not mean MPs were speaking less often: by contrast with the nineteenth century, many more of them were active participants in debate, although their speeches tended to be shorter. It was possible to get away with being idle - the Conservative Sir John Leigh remained completely silent throughout his 1922-45 Commons career - but the popular expectation was now that members would speak. ${ }^{64}$ However, when they did so, fewer of their colleagues were listening to them. In his evidence to the 1930-1 Select Committee on Public Business - appointed in an atmosphere of concern about whether parliament in its current form was capable of responding to the economic crisis - the long-serving Conservative MP Earl Winterton blamed the multiplication of committees for the fall in attendance in the Chamber. ${ }^{65}$

To-day it often happens that, even when a big issue is under review, the Minister in charge of the debate and the ex-Minister of the Department concerned, together with a Whip on each Bench, are the only occupants of the Front Benches for hours at a time, whilst the Back Benches are mainly occupied by a handful of members waiting to speak.

In breach of previous etiquette, MPs did not stay to listen to others, but often hurried away immediately they finished speaking themselves. ${ }^{66}$ It seems that, as time went on, senior ministers (who were of course extremely busy) became less inclined simply to sit and listen to debate. 'We are getting the atmosphere of a continental parliament', complained the Liberal MP Robert Bernays in 1932. 'The executive

\footnotetext{
61 Macmillan, Winds of Change, p.159.

62 These trends were starting to become apparent before 1918. Cecil Harmsworth, retrospective note of 23 June 1936, attached to diary entry of 8 April 1914, Cecil Harmsworth Papers, University of Exeter; Harold Nicolson to Robert Boothby, 7 June 1939, in Nigel Nicolson (ed.), Harold Nicolson: Diaries and Letters 1930-39 (London, 1966), p. 403. See also Arthur Ponsonby, 'At Westminster', New Leader, 30 March 1923.

63 Rennie Smith diary, 3 Feb. 1926, MS. Eng. Hist. d. 287, Bodleian Library.

64 Jennings, Parliament, p. 133; Rush, The Role of the Member of Parliament, pp. 140-1, 146-56.

65 The committee never issued a report but it did publish the evidence it gathered. For its significance, see Ronald Butt, The Power of Parliament (London, 1969), ch. 4.

66 Special Report from the Select Committee on Procedure, p. 330.
} 
may be supposed not to be separated from the legislature, but in fact it is. ${ }^{67}$

When an MP spoke and on what topic was not of course something over which they themselves had complete control. It was determined considerably by the nature of the business before the House, which itself was partly a matter of negotiation through 'the usual channels', i.e. between government and opposition whips. Being in the majority was not always an advantage from the individual point of view. 'Supporters of the Government of the day have always the thinnest time in opportunities for making personal reputations', observed one Tory. 'As a rule they can serve their leaders better by silence than by speech. ${ }^{68}$ The whips' desire for votes rather than speeches was of course nothing new. ${ }^{69}$ (On occasions, though, they needed to get their MPs to speak in order to prevent a debate from collapsing, thus maintaining the government's control of the parliamentary schedule.) Opposition provided better chances; indeed, the smaller the party the better the odds. 'With a party of sixty your leaders want you to put up a show for the party, and they don't care how bad a show you put up providing they don't associate themselves with you', recalled the Asquithian Liberal Frank Gray, adding: 'My leaders always were encouraging the young newcomers to make speeches, when it was not safe for themselves, and to ask questions which they would not themselves have asked.' Gray also noted the power of the whips in helping determine who would be called by providing a list for the Speaker. ${ }^{70} \mathrm{He}$, of course, would also exercise his judgement and might, for example, seek to empty an overexcited House by calling a renowned bore. ${ }^{71}$

In 1925, the Conservative MP Cuthbert Headlam estimated that out of 615 MPs only '50-odd speakers' were heard regularly (and he thought that none of those was worth listening to).$^{72}$ Waiting to be called was a stressful and potentially frustrating experience. Parliament was 'a place of undelivered speeches': an MP who was in the end overlooked might have put in hours of preparation to no account. ${ }^{73}$ Monotony, indeed, was an important feature of a member's life. Some relieved it by heavy drinking (doubtless contributing to rowdiness in the Chamber after the dinner hour). ${ }^{74}$ Others had times when they wondered why they had ever wanted to go to the Commons - days spent, as Headlam put it, 'hanging

${ }^{67}$ Smart, Bernays Diaries (Lampeter, 1996), p. 11 (entry for 3 Nov. 1932).

68 'The Man in the House' [pseudonym for a Conservative MP], 'Inside the House', The Man In the Street, July 1925.

69 Winston Churchill, Lord Randolph Churchill, I (London, 1906), p. 69.

${ }^{70}$ Gray, Confessions, pp. 124, 150.

71 Earl Winterton, Orders of the Day (London, 1953), p. 96.

72 Stuart Ball (ed.), Parliament and Politics in the Age of Baldwin and MacDonald: The Headlam Diaries 1923-1935 (London, 1992), p. 56 (entry for 12 March 1925). In 1918 there were 707 MPs; the numbers were reduced as a result of the creation of the Irish Free State in 1921-2.

${ }^{73}$ William Leach, 'After Eight Months', Socialist Review, Sept. 1923.

${ }^{74}$ Peter Clarke, The Cripps Version: The Life of Sir Stafford Cripps (London, 2002), p. 33; Jones, My Lively Life, p. 79. 
about, trudging through division lobbies, gossiping, smoking, pretending to do work - and just "carrying on" ${ }^{75}$ In these circumstances, a good speech, or even a bad joke, would stand out. 'Men who have been sitting for hours in a depressing atmosphere, many overwrought by the anticipation of their own speeches and the boredom produced of other people's, will readily laugh at very little', noted Gray. ${ }^{76}$

But if orators of even relatively modest ability could thus aspire to gain the ear of the House, Commons speaking remained an often rather thankless task. Even in the Victorian era it was 'an axiom cynically accepted in Parliament that a speech rarely, if ever, affects votes. ${ }^{77}$ In his evidence to the Select Committee Austen Chamberlain challenged this idea: 'Again and again, anyone of us who has been long in the House has seen a proposal withdrawn or amended out of recognition as a result of debate. ${ }^{37}$ However, he also decried the impact of recent trends:

that which in the olden days would have been decided on the floor of the House, and perhaps affected by the trend of the discussion in the House, is now sometimes decided upstairs in a Party meeting or a committee meeting of the Party, which really takes all the life out of the debate, and you merely come down to the House of Commons to register a decision which has been taken upstairs. ${ }^{79}$

Certainly, some speeches did have a real effect, as when Churchill saved the government's bacon during the debate on the Amritsar massacre, or during the controversy which led to the Commons rejecting the revised Anglican prayer book. ${ }^{80}$ The fact that Baldwin as prime minister regularly spent up to nine hours a day in the Commons - not all of this time in the Chamber, but available to intervene in debate if need be - is indicative of the importance placed on gauging the parliamentary atmosphere. ${ }^{81}$ There was, in fact, a significant element of unpredictability. If no MP stood much chance of swaying events with a single intervention, the collective mood of members was something that governments were obliged to take into account. This might be expressed by asides, laughter, barracking, or the waving of order papers, as much as through what members actually said in formal speeches. These methods of expressing

\footnotetext{
75 Ball, Parliament and Politics in the Age of Baldwin and MacDonald (London, 1992), p. 134 (entry for 23 Nov. 1927).

76 Gray, Confessions, p. 126.

77 Henry W. Lucy, A Diary of the Salisbury Parliament, 1886-1892 (London, 1892), p. 422.

78 Special Report from the Select Committee on Procedure, p. 225.

79 Ibid., p. 224.

80 Richard Toye, Churchill's Empire: The World That Made Him and The World He Made (London, 2010), pp. 152-4; Huw Clayton, 'The life and career of Sir William Joynson-Hicks, 1865-1932: a reassessment', Journal of Historical Biography, 8 (2010), pp. 1-38, at pp. 28-30. For the Prayer Book controversy as a whole, see John Maiden, National Religion and the Prayer Book Controversy, 1927-1928 (Woodbridge, 2009).

81 Williamson, Baldwin, pp. 74-8. See also Herbert Williams, Politics: Grave and Gay (1949), p. 103 .
} 
opinion - 'wild approving cheers' or 'ironical cheers and jeers' were a well-established and crucial part of the rhetorical culture of the Commons, and remained so in later years. ${ }^{82}$

That culture was also influenced by the way in which proceedings in parliament were reported. There was of course Hansard, but what really mattered - in the absence of film or audio recordings and of meaningful political reporting by the $\mathrm{BBC}$ - was the press. The requirements of newspapers affected the timing of speeches. In prior days, party leaders had spoken at eleven or twelve at night, providing the climax to the debate. Now, because the papers went to press sooner, they were 'almost obliged to speak early' in order to ensure that their remarks were reported.$^{83}$ By today's standards, the level of parliamentary coverage was luxuriant. In addition to incidents thought deserving of their own specific news items, the higher-brow papers carried extensive summaries of the proceedings; there might well be leader comment too. There were plenty of parliamentary sketch-writers, albeit none to rival the great Henry Lucy (who had retired in 1916). Coverage in the popular press - or the lack of it - was the chief target of MPs' criticism. Even at this end of the market, though, the Labour-supporting Daily Herald was notable during the 1920s for its worthy accounts of 'Sugar Subsidy Bill - Third Reading' and the like. ${ }^{84}$ Given that parliament now sat for longer than in the past - autumn sessions were ubiquitous after 1918 - it may have been harder for journalists to sustain their readers' interest.

Some MPs attempted to influence public perceptions through their own journalism. They published accounts or sketches of their own, sometimes in partisan weeklies or monthlies, but also in more mainstream publications. In the later 1920s, for example, Duff Cooper wrote a weekly column in the Saturday Review called 'The Comedy of Westminster', published under a pseudonym. (He recalled that this 'had the salutary effect of compelling my attendance at important debates on subjects in which I had little interest'. ${ }^{85}$ Chatting with lobby correspondents was an indirect method of trying to influence coverage, and the parties had their own media operations. The Labour Press Service, for example, issued from the party's headquarters, put a sympathetic gloss on events in the Commons, its interpretation being in turn strongly criticized by the other parties' publications. ${ }^{86}$ MPs' speeches, of course, were conditioned by the hope of getting coverage. As Snell noted,

\footnotetext{
82 Snell, Daily Life in Parliament, p. 39. For the later persistence of such techniques, see, for example, Eric Taylor, The House of Commons at Work (Harmondsworth, 1958), pp. 48-9, and Daniel Finkelstein, 'Cameron must silence the shouters', The Times, 9 Feb. 2011.

83 Comment of Austen Chamberlain: Special Report from the Select Committee on Procedure, p. 223.

${ }^{84}$ Laura Beers, Your Britain: Media and the Making of the Labour Party (Cambridge, MA, 2010), p. 92.

85 Cooper, Old Men Forget, p. 144.

${ }^{86}$ See 'Notes of the Month', The Lloyd George Liberal Magazine, May 1923.
} 
'Many of the speeches in the House appear to be made in the hope that they will be reported in the newspapers circulating in the particular constituencies the members represent, rather than that they will influence the mind of the House of Commons. ${ }^{97}$ But members grumbled that their efforts were often poorly reported. ${ }^{88}$

The concern with coverage helps explain the anxiety expressed by many MPs over what they saw as declining public engagement with the Commons. Churchill harked back to the days when, in spite of the smaller electorate, a large public followed politics 'as seriously they follow football matches'. He attributed their supposed loss of interest in part to the fact that more Bills were now taken in committee, reducing the drama on the floor of the House. ${ }^{89}$ Others blamed the masscirculation press. The Labour (formerly Liberal) MP J. M. Kenworthy complained that 'if somebody creates a disturbance in the gallery most of the newspapers report that, and give not one word to the Debate. ${ }^{90}$ Winterton bemoaned the fact that MPs now faced competition for publicity from 'film stars and cricketers ... We have all a feeling today that we are less important in the public eye than we were 25 years ago. 91 It was an irony that, although MPs were now speaking more often 'because they are obliged to do something to satisfy their constituents' (as Austen Chamberlain put it), those self-same constituents seemed to show little interest in the accounts of what they actually said. ${ }^{92}$ However, it is possible that MPs nostalgic for an earlier era exaggerated the extent of popular indifference. 'What has happened is that the "popular" Press has taught its readers to ignore that huge mass of Parliamentary debate that does not really matter', argued the Conservative political writer Philip Cambray. 'With what does matter, far more people are much more closely acquainted to-day than fifty - even twenty-five years ago - thanks to the extension of newspaper reading through the attractions of the "popular" Press. ${ }^{93}$ The Houses of Parliament were a common tourist destination, and tickets for the gallery were a valuable currency for members seeking to impress individual constituents. ${ }^{94}$ But popular pride in the institution could sit side by side with indifference to its proceedings. ${ }^{95}$

87 Snell, Daily Life in Parliament, p. 44.

88 See, for example, Benn diary, 17 June 1924, Stansgate Papers ST 66.

89 Special Report from the Select Committee on Procedure, pp. 146, 148.

90 Ibid., p. 308.

91 Ibid., pp. 336-7.

92 Ibid., p. 226. The pressure from constituents to speak was already noticeable by 1918: Hughes, Press, Parliament and Platform, p. 97.

93 Philip G. Cambray, The Game of Politics: A Study of the Principles of British Political Strategy (London, 1932), p. 123.

94 Ibid., pp. 123-4; 'Thirty-Three Division' [pseudonym], 'Some thoughts on electioneering', The Conservative Agent's Journal, March 1923.

95 Hastings, Autobiography, p. 231. 


\section{III}

As we have already seen, there were key elements of continuity in the House's rhetorical culture. The formal ceremonial aspects which provided an important part of the framework of rhetoric (such as the procession from Commons to Lords to hear the King's Speech) stayed essentially constant. In spite of some doubts about the feudal connotations of the 'gaudy display', Labour MPs in practice offered little challenge to it. ${ }^{96}$ But this is not to say that the culture remained static overall. The rhetorical atmosphere could be significantly different from one parliament to another. Winterton recalled that 'Compared with its pre-1914 predecessors, the House of Commons in 1919 was a very quiet and placid institution, since no great issue divided the parties, and both the Labour and the Liberal Oppositions were small and ineffective. ${ }^{97}$ However, the election of 142 Labour MPs in 1922 - up from 63 in 1918 - led to an increased number of parliamentary 'scenes' (which will be discussed below). Things were calmer by the end of the decade, and there was another stark shift after the 1931 election, at which Labour was reduced to around fifty MPs. The party made a fair recovery in 1935, but the continued overwhelming predominance of National Government MPs reduced the sense of unpredictability inherent in the three-party politics of the 1920s. If a shock government defeat was unlikely, the interest of debate was at one level diminished, although this is not to say that major issues such as India, defence and foreign policy did not continue to provide thrilling spectacle. At the same time, the scope for dramatic parliamentary manoeuvre à la Disraeli diminished still further.

The chosen style of the Speaker could also have an impact on the rhetorical atmosphere. There were three Speakers in the inter-war years: J. W. Lowther (who served from 1905 to 1921), J. H. Whitley (1921-8) and E. A. Fitzroy (1928-43). Lowther muttered his sarcastic disapproval during speeches he found tedious; Fitzroy drummed his fingers when he thought an MP had spoken too long, 'a fairly effective method of unofficial closuring' ${ }^{98}$ Whitley was in some ways the most significant of the three, in that he presided over a House that for the first time included a large number of Labour MPs. It was his view that, inexperienced in customs and procedure as they were, it was necessary 'to drive them on a loose rein' ${ }^{99}$ This brought him criticisms from some Conservatives for excessive laxity, but others defended him, on the grounds that stricter treatment would play into the hands of the disrupters. ${ }^{100}$ On balance, he

\footnotetext{
96 L. MacNeill Weir, 'Shaking the cobwebs from the ceiling at Westminster', Forward, 2 Dec. 1922

97 Winterton, Orders of the Day, p. 92.

98 Ibid., p. 96.

99 Hemingford, Back-Bencher and Chairman, p. 31.

100 For example, 'The Man in the House', 'Inside the House', The Man in the Street, Aug. 1926.
} 
was probably quite effective in his efforts to guide Labour into the approved channels of behaviour. ${ }^{101}$

Nevertheless, Labour was presented by its enemies as posing a substantial threat to parliamentary rhetorical traditions and culture. (We have already seen how Labour MPs' alleged 'street-corner' style was an object of criticism.) This culture was idealized in a variety of ways by figures across the political spectrum; although Labour politicians did not make a fetish of parliament to the extent that is sometimes suggested, some of them were active participants in this process. 'The House of Commons, though critical, is always fair' was a typical sentiment, expressed in this instance by the Coalition Liberal (and later Liberal National) MP Geoffrey Shakespeare. ${ }^{102}$ Party sentiment would supposedly dissolve in the face of rhetorical excellence. 'When a really good speech is made the House as a whole is delighted', claimed Snell. 'It is the most critical assembly in the world; but it is also the most

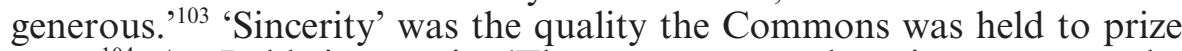
most. ${ }^{104}$ As Baldwin put it, 'The most unpopular views among the majority - views held, perhaps, by only one or two men - are listened to respectfully, so long as the House believes that honesty is behind them.' ${ }^{105}$ In his autobiography, John Buchan (who served as a Conservative MP from 1927 to 1935) provided an able summing up of the clichés, even whilst acknowledging that they were clichés:

The customary platitudes about the House of Commons happen to be true. Individual members may be ill-bred; the House itself has a fine taste and breeding, and a sure instinct in matters of conduct. It will always include people who are foolish, hasty, humourless; but collectively it is rarely other than patient, urbane and wise. It is nicely discriminating, for while it will tolerate an agreeable buffoon and an honest donkey, it will not give its confidence except to sterling character and talent. Securus judicat. The flashy platform demagogue has to change his methods if he is to win its favour. It demands specific qualities - a certain decency in debate and a certain respect for itself and its ancient ritual. ${ }^{106}$

The strength of the Commons, in this analysis, was its ability to transcend both the weaknesses of its members and changes across time. This was linked both to rhetorical style (which revealed character) and to the desirability of conforming to tradition. Speeches, therefore, should demonstrate both clarity and self-control. To quote Snell again, the keys to good parliamentary speaking were 'clearness, simplicity, restraint. The House of Commons will not be preached to or shouted at;

101 Ralph Verney to Lord Hemingford, 5 Jan. 1945, J. H. Whitley Papers, University of Huddersfield.

102 Geoffrey H. Shakespeare, 'Impressions of the new parliament', British Weekly, 14 Dec. 1922.

103 Snell, Daily Life in Parliament, pp. 45-6.

104 Swinton, I Remember, p. 265.

105 Stanley Baldwin, The Torch I Would Hand to You (London, 1937), p. 140.

106 John Buchan, Memory Hold-the Door (London, 1940), p. 228. 
under-statement will influence it far more than exaggeration; it does not like verbosity. ${ }^{107}$ This of course was connected to the 'conversational' style of speech discussed above. In Conservative hands, moreover, the qualities of quietness and restraint took on an unstated class dimension: they were linked to the supposedly unchanging character of the Commons across generations. This was compared in turn to the traditions of institutions dominated by the wealthy. 'Like a great public school or one of the old Universities' the Commons had 'a continuity of spirit or outlook which neither alterations in personal composition nor fluctuations of party fortune can materially vary.' ${ }^{108}$ Thus when the press reported that parliament had reassembled 'quietly', it was to be understood that "the word "quiet" does not mean the opposite of "noisy," but merely the simplicity, and lack of ceremony, with which a famous man dines quietly at his club.' ${ }^{109}$ Thus a construction of the nature of the Commons that on the surface appeared class neutral character, talent and sincerity being sufficient to gain anyone a hearing - was established at least partially in terms of behavioural tests that reflected elite values and codes. There was also a link to Conservative efforts to win over non-conformist opinion as the Liberal Party collapsed. Ross McKibbin has noted that the Conservative Party refashioned itself in order to appeal to this group: 'Many of its older, rhetorically aggressive traditions were abandoned in favour of a more reticent and sanctimonious style', as personified by Baldwin and Sir William Joynson-Hicks (home secretary, 1924-9). ${ }^{110}$

\section{IV}

The 'customary platitudes' were doubtless genuinely believed by those who articulated them, but they romanticized a reality in which the quality of Commons debate could seem 'quite extraordinarily low' and the sittings 'long \& dreary'. ${ }^{111}$ Its class dimension notwithstanding, the myth cannot be dismissed simply as a partisan one, given that it had adherents within all parties. It could, however, be employed as a resource in partisan debates surrounding parliamentary conduct. These were particularly intense in 1922-3, a moment of true socio-political flux. Lloyd George had been dethroned, Bonar Law's Conservatives

\footnotetext{
107 Snell, Daily Life in Parliament, p. 46 (emphasis in original). For the British political 'culture of restraint' and its connections with ideas about masculinity and national identity, see Martin Francis, 'Tears, tantrums, and bared teeth: the emotional economy of three Conservative prime ministers, 1951-1963', Journal of British Studies, 41 (2002), pp. 354-87.

108 Robert S. Angus, 'The New House', The Man In the Street, May 1925.

109 'The Game of Life by "Centre-Forward"', The Man in the Street, March 1925.

110 Ross McKibbin, Classes and Cultures: England 1918-1951 (Oxford, 1998), p. 96.

111 Ball, Parliament and Politics in the Age of Baldwin and MacDonald, p. 56 (entry for 12 March 1925); William Bridgeman to F. S. Oliver, 9 Aug. 1928, in Philip Williamson (ed.), The Modernisation of Conservative Politics: The Diaries and Letters of William Bridgeman (London, 1988), p. 216.
} 
had triumphed at the polls, and Labour had displaced the Asquithian Liberals as the official opposition. (However, Labour still had to share the front bench with the Asquithians, and their respective party leaders literally jostled each other for space on it.) $)^{112}$ The inter-war economic crisis inevitably affected the content and character of parliamentary debate. In the face of the social devastation wreaked in some regions by mass unemployment, many of the new Labour MPs, and especially those of the left-wing-dominated Clydeside group, were determined to present themselves in parliament as the champions of the poor. Controversy centred partly on the passion and stridency of their rhetorical technique. To their sympathizers, their eager contributions were 'a great demonstration of the workers' claim for a human life' and 'a measure of the difference between the old Ruling Class type of MP and the representatives of Labour'. ${ }^{113}$ To their detractors, their street-corner style was not merely inappropriate but, in combination with class-conscious language, resulted in speeches of 'Bolshevist frightfulness' designed to bring parliament into contempt. ${ }^{114}$ What left-wingers depicted as a morally forceful type of speech intended to awaken the Commons (and the nation) to its responsibilities was privately deplored by moderates such as MacDonald and portrayed by Conservatives as a 'hymn of hate' chanted by sour and fanatical class warriors. ${ }^{115}$

The technique and content of formal speeches was not the only issue, however. Some Labour members were keen to use parliamentary disruption tactics in order to draw attention, in particular, to the issue of unemployment. This was presented by them as a proper use of the Commons to challenge capitalism and to 'put a fighting spirit into the working-class outside'. ${ }^{116}$ 'By all night sittings, by organised guerrilla opposition, which anyone is free to call "obstruction," for all we care, Labour is making it impossible to forget the unemployed', declared the ILP weekly The New Leader in December 1922. ${ }^{117}$ The year 1923 saw some spectacular parliamentary 'scenes'. One of the most notorious attempts to disrupt business arose over the question of the government's treatment of ex-servicemen, and involved the singing of The Red Flag within the Chamber. Eventually the Speaker suspended the sitting. ${ }^{118}$

\footnotetext{
112 L. MacNeill Weir, The Tragedy of Ramsay MacDonald: A Political Biography (London, 1938), pp. $110-1$.

113 'The debate', Daily Herald, 24 Nov. 1922; 'What will they do with it?', Daily Herald, 25 Nov. 1922.

114 'Frightfulness in parliament', Morning Post, 25 Nov. 1922.

115 Angus, 'The new house'. Privately, though, some Conservatives thought that the media was exaggerating. Earl Winterton wrote in his diary for 24 Nov. 1922: 'The press is making a lot of the "new spirit" infused by the Labour Phalanx, but all that they say might be a rehash of what they said [about the Liberal election victory] in 1906 and I think this is a smaller bouleversement than that' (Winterton Papers, 30, Bodleian Library).

116 David Kirkwood to the editor of The New Leader, dated 26 March 1923 and published in the issue of 30 March.

117 'Politics \& Work', New Leader, 15 Dec. 1922.

118 'Uproar in the Commons', The Times, 12 April 1923.
} 
Some within the Labour Party, notably MacDonald, disapproved of such episodes (which may have been painted by the copy-hungry press as more exciting than they really were). ${ }^{119}$ Conservatives and Liberals, of course, presented the Red Flag episode as proof of Labour's innate extremism and unfitness to govern. Crucially, the party's enemies were able to invoke the 'customary platitudes' as part of their case. The disrupters, it was alleged, offended against the dignity and traditions of the Commons, and showed themselves devoid of the 'reverence for the ancient institutions of state'. ${ }^{120}$ As one writer in the Lloyd George Liberal Magazine put it, "To cause the recesses of the Chamber to re-echo the strains of the "Red Flag" is not the step that politicians would naturally take if they wished to convince the electorate that their party ought to be entrusted with the reins of government., 121

The idea that Labour actions insulted the dignified and fair-minded traditions of the House had an obvious power, not least because it chimed with the concurrent (and novel) rejection of heckling and 'rowdyism' in extra-parliamentary situations. ${ }^{122}$ However, there was also a serious problem with this interpretation, in that disorderly conduct and the shouting-down of opponents in the Commons was in fact behaviour with a long-established pre-1918 heritage. 'What is usually called a spirit in the House generally shows itself in what resembled rage', observed one MP in $1719 .{ }^{123}$ In the first part of the nineteenth century there were some spectacular 'scenes', some of which involved MPs disrupting each other by making impressive imitations of animal noises. ${ }^{124}$ More recent and pertinent points of reference were the obstructive tactics of Parnell's Irish nationalists and the behaviour of the Conservatives during the pre-war Home Rule controversy. From 1911 - the start of Bonar Law's first period of leadership - the Tories had adopted a new confrontational style in parliament. In November 1912 - in an episode which Labour MPs took as a precedent in 1923 - they had attempted to hold up the business of the Commons, which led to the suspension of the sitting. ${ }^{125}$ The Liberal Magazine, therefore, could present Labour disruption as a game which the party had 'taken over from the extreme Tories'. ${ }^{126}$ (Labour was also accused of taking over the tactics of the Irish.) ${ }^{127}$ The Conservatives, more importantly, were obviously vulnerable to charges of hypocrisy. During the debate on the King's Speech in

119 Howell, MacDonald's Party, pp. 29, 37; Snell, Daily Life in Parliament, p. 50; 'The Man in the House', 'Inside the House', The Man in the Street, Feb. 1926.

${ }_{120}$ F. John Sherwood, 'If socialists ruled', The Popular View, May 1923.

121 'That reminds me, by R. W. A.', Lloyd George Liberal Magazine, May 1923.

${ }^{122}$ Lawrence, 'The transformation of British public politics'.

123 Jeremy Black, Debating Foreign Policy in Eighteenth-Century Britain (Farnham, 2011), p. 71.

124 'One of no party', Random Recollections of the House of Commons, From the Year 1830 to the Close of 1835 (London, 1836), pp. 68-79.

125 'Uproar in the Commons', The Times, 12 Apr. 1923.

126 'Notes of the month', Liberal Magazine, Jan. 1923.

127 'That reminds me, by R. W. A.'. 
1922, MacDonald reminded them of their 'furious onslaughts' over Home Rule. Indeed, 'I have heard the right hon. Gentleman [Bonar Law] from this box threaten the country with civil war. ${ }^{128}$ Criticisms of Labour disorderliness were therefore humbug. ${ }^{129}$ Furthermore, although Conservative disorder had undoubtedly diminished since those days, it was by no means wholly a thing of the past, which could be seen as a sign of ongoing double standards. The Labour MP Hugh Dalton complained early in the life of the 1924 parliament that 'there has been up to now been a good deal more noise and interruption from the Tory benches than from ours ... But I do not find these incidents reported in anti-Labour newspapers, which are always ready to magnify into a "disorderly scene" any similar incidents on our side."130

It would therefore have been difficult for Labour's opponents to maintain that all forms of disruption were wrong, and in fact they did not attempt to do so. 'We do not regard a disturbance in the House of Commons as necessarily an evil,' chided the Liberal Magazine, 'but there ought to be some reason for it.' 131 'Scenes', then, could be acceptable, but only if they arose spontaneously in the face of incitements by the other side. The key charge against Labour was that it engineered disturbances, planning them in advance in a Leninist effort - as Conservatives sometimes alleged - 'to make Parliamentary Government impossible'. ${ }^{132}$ Meanwhile, Labour efforts to revive the memory of Torysponsored disturbances failed 'to appreciate that these were the spontaneous outcome of strong and genuine feeling, not premeditated attempts to bring proceedings to a close, or to be personally offensive to opponents'. ${ }^{133}$ The defenders of Labour 'scenes' - who included MacDonald on occasion, although he did not in reality like such episodes of course claimed that they were the result of sincere emotions, forced to boiling point by the affronts of opponents. ${ }^{134}$ You orchestrate rowdyism; I express my legitimate anger with vigour in the face of intolerable provocations.

However, some MPs and commentators eschewed moral grandstanding in favour of world-weary superiority. They acknowledged that all parties at times participated in 'scenes', but argued that such actions were futile or self-defeating. ${ }^{135}$ It was also sometimes suggested that, as they gained in experience, Labour MPs would learn this, as part of a

\footnotetext{
128 Parliamentary Debates, House of Commons, 5th ser., vol. 159, 23 Nov. 1922, col. 50.

129 J. Ramsay MacDonald, 'The party in parliament', Socialist Review, Jan. 1923.

130 Hugh Dalton, 'First impressions of parliament', New Leader, 2 Jan. 1925.

131 'Notes of the month', Liberal Magazine, Jan. 1923.

132 “ "Red flag" in parliament', The Popular View, May 1923.

133 'The Man in the House', 'Inside the House', The Man in the Street, June 1927.

134 MacDonald, 'The party in parliament'; Jones, My Lively Life, pp. 73-4.

135 'Notes of the month', Liberal Magazine, Jan. 1923; 'First citizen' [Alfred Duff Cooper], 'The comedy of Westminster', Saturday Review, 3 July 1926; 'The Man in the House', 'Inside the House', The Man in the Street, Aug. 1926; 'What is parliament for?', Liberal Pioneer, June 1927.
} 
natural response to 'the moderating influence of the House'. ${ }^{136}$ Tory propaganda cartoons belittled Labour MPs as misbehaving puppies or children, who needed forced instruction in 'parliamentary manners'; and also ridiculed them by the suggestion that they would not be able to avoid being 'taken in hand'. A typical sentiment was: 'Experts say that the Old Mother of Parliaments knows how to make her unruly children respect her.'137 This was the sharp edge of the 'customary platitudes', which asserted that new MPs must either adapt themselves to the ways of the House, or face marginalization by the collective. During the later 1920s, then, continued criticisms of Labour 'hooliganism', indiscipline and lack of debating skill sat side by side with triumphalist claims that the Commons magic was working its taming effect. ${ }^{138}$ Later still, when some of the dust had settled on the controversies of the 1920s, types of behaviour that had once been seen as 'rowdyism' could be reinvented as a quaint and humorous subject for parliamentary nostalgia. ${ }^{139}$

It may well seem that the triumphalists were right, and that, as Miliband suggests, the Commons turned 'erstwhile agitators into subdued parliamentarians'. ${ }^{140}$ Certainly, the attacks on Labour's Commons methods subsided after the 1920s, to the point where Baldwin could praise the party in 1935 for having 'helped to keep the flag of Parliamentary government flying'. ${ }^{141}$ However, although Labour undoubtedly did adapt itself to the parliamentary 'community of practice', its integration did not leave that community entirely unchanged. Snell declined to wear traditional court dress when proposing the 'humble address' in reply to the 1929 King's Speech, and wore 'ordinary morning dress' instead. ${ }^{142}$ Another Labour MP, Jack Jones, helped put paid to the habit - already in long-term decline - of using Latin tags, "which he would invariably greet with a stentorian roar: "That is the winner of the two-thirty". ${ }^{143}$ Labour MPs also affected the rhetorical atmosphere in intangible ways: they spoke 'racily and idiomatically', providing a contrast with the 'ordinary clipped talk of the public schools

\footnotetext{
136 Andrew Bonar Law to George V, 1 Dec. 1922, Baldwin Papers, 60.

137 The Popular View, May 1923.

${ }^{138}$ For strong criticisms, see 'First Citizen' [Alfred Duff Cooper], 'The Comedy of Westminster', Saturday Review, 3 July 1926; M. J. Landa, 'Labour's parliamentary failure', Liberal Magazine, April 1927; Baldwin to George V, 17 Nov. 1927, Baldwin Papers, 62. For suggestions of growing conformity by Labour MPs, see 'The Man in the House', 'Inside the House', The Man in the Street, Aug. 1926, and 'Quill, MP', 'Pen pictures from parliament', Home and Politics, Nov. 1928.

139 Transcript of 'Answering you - no. 101', broadcast 28 June 1943, p. 10, Parliamentary Archives, $\mathrm{HC} / 50 / 2 / 4$.

140 Miliband, Parliamentary Socialism, p. 95.

141 Parliamentary Debates, House of Commons, 5th ser., vol. 302, 22 May 1935, col. 371.

142 Lord Snell, Men, Movements and Myself (London, 1936), p. 226.

143 Mosley, My Life, p. 211. Latin quotations did not die out entirely, but when Leo Amery used one to make a quip at Churchill's expense on a well-known occasion in 1934 his joke relied on the fact that he knew he could depend on Churchill asking for a translation (Toye, Churchill's Empire, p. 186). But as Meisel points out, classical quotation had been used only sparingly even in the age of Pitt and Fox: Public Speech, pp. 57-60.
} 
and universities'. ${ }^{144}$ These changes were not revolutionary, but they made significant differences to the lived experience of parliament.

\section{V}

This article has shown that the rhetorical culture of the House of Commons was an important point of contention in post-1918 politics, the contest being linked to issues surrounding class, emotional bearing, capacity for government, as well as to 'the claim to represent'. ${ }^{145}$ Seemingly bland claims about the impersonal capacity of the Commons to enforce conformity with the rhetorical 'traditions of the House' could in fact be deployed as a potent political weapon. The asserted norms were by no means ideologically neutral but were affirmed by those who posed as traditionalists to marginalize styles and methods of argument that they found threatening, in effect those of working-class radicals. (This is not to say that the defenders of 'tradition' were necessarily cynics.) Lawrence has suggested that 'Most inter-war politicians wanted to substitute a deliberative for a demonstrative model of citizenship'. ${ }^{146}$ Arguably, the deliberative, 'conversational' style of rhetorical behaviour did win out in the Commons, although not, perhaps, unequivocally and certainly not without meeting serious challenge. Whereas the eventual rise of Clement Attlee represented a victory for clipped accents and controlled feelings, the party he led after 1935 also held Aneurin Bevan, master of soaring emotion and the rhetorical heir to Lloyd George. And whereas Churchill's style may have sat uncomfortably with the dominant 'emotional economy' of the time, no one doubted that he was a brilliant speaker, suspicious though many people were of this talent. ${ }^{147}$ His excursions into conversationalism were short-lived.

We should not, though, confuse a deliberative style with the substance of deliberation. Some contemporaries felt that the increased use of the guillotine - a device for curtailing discussion in order to get business through - damaged the Commons' role as a deliberative assembly by sacrificing genuine debate in the interests of pushing through more and more legislation. ${ }^{148}$ (It was already clear in the Edwardian period that the power of initiative lay with the Cabinet not the Commons.) ${ }^{149}$ Others in fact disparaged the idea that speeches should change votes: it was not encouraging to think that MPs might be

\footnotetext{
144 Buchan, Memory Hold-the Door, p. 228.

145 For the last of these, see Jon Lawrence, Speaking for the People: Party, Language and Popular Politics in England, 1867-1914 (Cambridge, 1998).

146 Lawrence, Electing our Masters, p. 128.

147 Francis, 'Tears, tantrums, and bared teeth'.

148 Comments of Earl Winterton: Special Report from the Select Committee on Procedure, pp. 332-3.

149 A. Lawrence Lowell, The Government of England, I (New York, 1912), p. 327.
} 
'swayed by specious rhetoric'. ${ }^{150}$ As the fictional Mrs Maggs observed in a story in the Conservative Home and Politics magazine: 'Why, how should we ever get anything done in Parliament, if everybody just voted according as they fancied, sometimes one way and sometimes another? ${ }^{151}$ The collapsing Liberal Party might still pride itself on the value it set on deliberation - what Bagehot had called 'government by discussion' - but that was perhaps a token of its powerlessness to do anything else. ${ }^{152}$ The main parties, with their greater and growing emphasis on discipline rather than on individual conscience, on the whole preferred parliament to act as a factory for processing programmes than as a 'talking shop'. ${ }^{153}$ These trends may well have accelerated after the perceived 'failure' of parliament in the run-up to and during the economic and political crisis of $1931 .{ }^{154}$ As Ronald Butt has noted, 'In the 1930s Parliament was under suspicion because it failed to solve the great contemporary problem' - unemployment. ${ }^{155}$

Did, then, the Commons decline in the inter-war years, and if so to what extent did rhetorical culture reflect or cause this? Some, such as Churchill, detected a reduction in parliament's prestige. The pre-1914 Commons, he claimed in 1938, was 'a far more living powerful entity in our national life than it is now', even though far fewer MPs in the previous era 'felt able to make a speech at all'. ${ }^{156}$ If decline did occur, however, it must be put into perspective. First, people had been alleging a decline from a supposed 'golden age' of parliamentary oratory since time immemorial. ${ }^{157}$ It was clearly very much less serious than the collapse of faith in parliamentary institutions that took place during the same period in countries such as Germany, Italy and Spain. Nor was there any irreversible decline: at the close of the Second World War the Commons stood high in public esteem, a phenomenon accompanied by a boom in the sales of Hansard. ${ }^{158}$ Moreover, Churchill was at one with

\footnotetext{
150 'First citizen' [Alfred Duff Cooper], 'The comedy of Westminster', Saturday Review, 24 Dec. 1927. The context for Cooper's remarks was the prayer book debate, which had been marred by anti-Catholic sentiment.

151 " "Doing your bit": Mrs. Maggs on the recruiting campaign', Home and Politics, Feb. 1929 (emphasis in original). For the significance of this character, see David Jarvis, 'Mrs. Maggs and Betty: the Conservative appeal to women voters in the 1920s', Twentieth Century British History, 5 (1994), pp. 129-52.

152 'What is parliament for?', The Liberal Pioneer, June 1927. This sort of idealism may be contrasted with the mood in the Liberal Party at the time of the hated Ottawa trade agreements a few years later: 'we ought to keep these bloody Tories up all night to show them what obstruction can be' (Smart, Bernays Diaries, p. 11 (entry for 3 Nov. 1932) ).

${ }^{153}$ Hugh Dalton, Practical Socialism for Britain (London, 1935), p. 46.

154 Middlemas, Politics in Industrial Society, pp. 325, 328.

155 Butt, Power of Parliament, p. 130.

156 Churchill, 'Memories of parliament', p. 421. Compare this with his earlier, more optimistic assessment: 'The Romanes Lecture', The Times, 20 June 1930.

157 See Meisel, Public Speech, ch. 2. Note also the distinction made by Lord Curzon in his Rede Lecture prior to the First World War. In his view, the high art of 'Oratory' had all but died out, whereas the lesser accomplishment of 'Eloquence' continued: Modern Parliamentary Eloquence (London, 1913), p. 2.

${ }^{158}$ Norton, 'Winning the war but losing the peace'; Taylor, The House of Commons at Work, p. 7.
} 
many others in finding that the intelligence of the Members was no greater' in former days than latterly. ${ }^{159}$ Amongst veterans, there was a view that the general standard of debate was rather higher than before the war, even though the number of top-rate speakers who could fill the chamber had gone down. ${ }^{160}$ Thus an increase in the average quality of contributions was compatible with the sensation that - in the words of the Tory MP Bob Boothby, first elected in 1924 - 'As time went on the House of Commons became perceptibly duller'. ${ }^{161}$

Boothby blamed the influence of Baldwin who, he claimed, had 'set himself the task of lowering the temperature of political life to zero'. ${ }^{162}$ This was too simplistic. It is certainly true that he and other Conservatives wanted to contrast Labour's 'violent and abusive tactics' in parliament with their own 'remarkable patience and conciliation' there. ${ }^{163}$ But although their efforts to associate their own oratorical style with political virtue did have some success, partisan factors alone are not sufficient to explain the changes in rhetorical culture. We need to look also to the shifting nature of the bargain between voters and the political classes in the era of universal suffrage, growing state and executive power, and increasingly professionalized politics. On the one hand, there was a continuation of a longstanding shift from a discursive to a programmatic view of statecraft, whereby the purpose of parties was to promise detailed policies and then deliver their implementation. On the other hand, there was a growth in the power of the state bureaucracy and the corporatist interest groups that it increasingly needed to appease. $^{164}$

But if this diminished the power of parliament to initiate law-making (or even to restrain government action), it was not simply that the executive sucked power away from the legislature. Rather, the increased volume of legislation required members to be more loquacious but also gave them less time to listen to their colleagues. This was in part because of increased committee work but also because MPs faced new demands from their constituencies. They were now paid (from 1911) and received free rail travel to their constituencies (from 1921). This seems to have helped create a culture of expectation in which voters bombarded their MPs with letters and visits - often requesting patronage, or help with problems surrounding post-war demobilization - and local parties required their members' presence in the constituency each weekend. ${ }^{165}$ Irritating as such demands often were, some MPs actively courted this

\footnotetext{
159 Churchill, 'Memories of parliament', p. 421.

160 Comments of Austen Chamberlain and Earl Winterton: Special Report from the Select Committee on Procedure, pp. 233, 328.

161 Lord Boothby, My Yesterday, Your Tomorrow (London, 1962), p. 31.

162 Ibid., p. 32.

163 Baldwin to George V, 17 Feb. 1927, Baldwin Papers 62.

164 Middlemas, Politics in Industrial Society.

165 Jennings, Parliament, pp. 28-9; Snell, Men, Movements and Myself, p. 213; Jones, My Lively Life, pp. 82-6; 'Quill MP', 'Pen pictures from parliament', Home and Politics, Feb. 1929.
} 
role (although it should be acknowledged that many others did not, and that the pressures were doubtless much less strenuous than they are today). ${ }^{166}$ MPs thus lacked the time to attend the chamber - or at least felt that they did. And, as Earl Winterton commented, if the Commons was not, as it were, 'interested in its own proceedings, it can hardly expect to interest the Press and the Public in them'. ${ }^{167}$ If the rhetorical culture of the House of Commons lost some of its vibrancy in the inter-war years, then, this was only partly the result of politicized changes in the style of oratory. As the purpose of parliament changed, MPs had less time for deliberation even as disruption fell out of favour. Today, it is considered a truism that MPs' rowdy behaviour brings parliament into disrepute. ${ }^{168}$ Yet, in spite of the allegations of its enemies, the Commons in the inter-war years seems to have suffered far less from Labour 'rowdyism' than from the pressures of programmatic politics and - to a lesser extent - the growing cult of 'the hard-working MP'.

\footnotetext{
166 Winterton diary, 14 Feb. 1919, Winterton Papers, 22.

167 Special Report from the Select Committee on Procedure, p. 330.

168 The current Speaker, John Bercow, recently told MPs: 'There's far too much noise in this chamber, which makes a very bad impression on the public as a whole' (BBC News Online, 27 April 2011).
} 